\title{
HUBUNGAN PERILAKU HIDUP BERSIH DAN SEHAT (PHBS) DENGAN KEJADIAN DIARE PADA BALITA
}

\author{
Relation Clean And Healthy Living Behavior With The Incidence Of Diarrhea \\ In Infants
}

\author{
Hilda Irianty ${ }^{1}$, Ridha Hayati ${ }^{2}$, Yeni Riza ${ }^{3}$ \\ Fakultas Kesehatan Masyarakat Universitas Islam Kalimantan Banjarmasin \\ Email: hildanafarin@gmail.com
}

\begin{abstract}
ABSTRAK
Diare merupakan masalah kesehatan masyarakat dengan angka kesakitan dan kematian yang tinggi, terutama pada kalangan balita. Penelitian ini bertujuan untuk mengetahui hubungan perilaku hidup bersih dan sehat dengan kejadian diare pada balita. Penelitian ini adalah penelitian survey analitik dengan rancangan cross sectional serta analisis chi square. Penelitian dilakukan di wilayah kerja Puskesmas Martapura Barat dengan jumlah sampel 76 responden ibu yang memiliki balita. Hasil penelitian ada hubungan antara pemberian ASI eksklusif dengan kejadian diare (P value $0.000<\alpha=0.05$ ). tidak ada hubungan antara penimbangan balita dengan kejadian diare ( $P$ value $0.293>\alpha=0.05$ ). Ada hubungan antara penggunaan air bersih dengan kejadian diare ( $\mathrm{P}$ value $0.026<\alpha=0.05$ ). Ada hubungan antara penggunaan jamban sehat dengan kejadian diare ( $P$ value $0.049<\alpha=0.05$ ). Ada hubungan antara perilaku cuci tangan pakai sabun dengan kejadian diare (P value $0.001<\alpha=0.05$ ). Perilaku hidup bersih dan sehat belum sepenuhnya diterapkan dengan baik di wilayah kerja Puskesmas Martapura Barat, hal ini dapat menyebabkan kejadian diare pada balita. Perlu adanya peningkatan program promosi kesehatan dari Puskesmas Martapura Barat, terutama tentang penerapan PHBS yang baik dan benar.
\end{abstract}

Kata Kunci ～: PHBS, Diare, Balita

\section{ABSTRACT}

Diarrhea is a public health problem with morbidity and mortality, especially in the toddler.This study aims to determine the relationship of the behavior of clean and healthy life with the incidence of diarrhea in infants. This research is analytic survey with cross sectional design and chi square analysis. The study was conducted in Puskesmas Martapura West with a sample of 76 respondents mothers who have children.The results of the study the relationship between exclusive breastfeeding with the incidence of diarrhea ( $P$ value $0.000<\alpha=0.05$ ). there is no relationship between a child's weight with the incidence of diarrhea ( $P$ value $0.293>\alpha=0.05$ ). There is a relationship between the use of clean water with the incidence of diarrhea ( $P$ value $0.026<\alpha=0.05$ ). There is a relationship between the use of healthy latrines with the incidence of diarrhea ( $P$ value $0.049<\alpha=0.05$ ). There is a relationship between handwashing with soap by the incidence of diarrhea ( $P$ value $0.001<\alpha=0.05$ ). Clean and healthy living behavior has not been fully implemented well in Puskesmas Martapura West, this can cause the incidence of diarrhea in infants . An improvement in the health promotion program of Puskesmas Martapura Barat, especially on the application of PHBs is good and right.

Keywords : : PHBS, Diarrhea, Toddler

\begin{tabular}{lll}
\hline Sekretariat & \multicolumn{2}{l}{ Article History: } \\
Editorial: Kampus FKM UNISMUH PALU - Palu 94118, & $\Rightarrow \quad$ Received 27 Februari 2018 \\
$\quad$ Sulawesi Tengah, Indonesia & $\Rightarrow \quad$ Revised 16 Maret 2018 \\
Telp/HP: +6281245936241, Fax (0451) 425627 & $\Rightarrow$ & Accepted 20 April 2018 \\
E-mail: jurnal.mppki@gmail.com & $\Rightarrow$ & Available online 25 Juni 2018 \\
OJS: http://jurnal.unismuhpalu.ac.id/index.php/PJKM &
\end{tabular}




\section{PENDAHULUAN}

Diare merupakan salah satu penyakit berbasis lingkungan yang menjadi penyebab utama kesakitan dan kematian. Berdasarkan data World Health Organization (WHO), Diare menempati urutan kelima dalam 10 penyakit penyebab kematian di dunia (WHO, 2011). Selain itu, penyakit Diare sering menyerang pada bayi dan balita, bila tidak diatasi lebih lanjut diare akan menyebabkan dehidrasi dan berujung kematian (Fauziah, 2013).

Survei morbiditas yang dilakukan di Indonesia oleh subdit Diare, Departemen Kesehatan dari tahun 2000 s/d 2010 terlihat kecenderungan insiden naik. Pada tahun 2000 IR penyakit Diare 301/ 1000 penduduk, tahun 2003 naik menjadi 374 /1000 penduduk, tahun 2006 naik menjadi 423 /1000 penduduk dan tahun 2010 menjadi 411/1000 penduduk. Kejadian Luar Biasa (KLB) diare juga masih sering terjadi, dengan CFR yang masih tinggi. Pada tahun 2008 terjadi KLB di 69 Kecamatan dengan jumlah kasus 8133 orang, kematian 239 orang (CFR 2,94\%), tahun 2009 terjadi KLB di 24 Kecamatan dengan jumlah kasus 5.756 orang, dengan kematian 100 orang (CFR 1,74\%), sedangkan tahun 2010 terjadi KLB diare di 33 kecamatan dengan jumlah penderita 4204 dengan kematian 73 orang (CFR 1,74 \%.) (Soepardi, J, 2011).

Wilayah kerja Puskesmas Martapura Barat, yang berada di kawasan sungai cenderung masih menggunakan air sungai yang tercemar oleh limbah rumah tangga, masyarakat kurang mementingkan kondisi air bersih yang layak mereka gunakan, hal itu terlihat dari perilaku masyarakat yang ada masih belum menerapkan pola hidup bersih dan sehat, berdasarkan data dari Puskesmas Martapura Barat, penduduk dengan akses sanitasi layak (Jamban Sehat) hanya berkisar 20,7\%, yaitu berjumlah 3.884 dari 17.829 penduduk. Hal tersebut dapat berdampak bagi kurangnya kualitas air bersih, sehingga berdampak pada timbulnya penyakit Diare. Dari data Profil Kesehatan Dinas Kesehatan Kabupaten Banjar tahun 2015, Diare menempati urutan ke 4 untuk penyakit menular langsung, yaitu berjumlah 10.425 pada tahun 2014, dan meningkat pada tahun 2015 menjadi 10.845 kasus. Sedangkan data jumlah kasus Diare di wilayah kerja Puskesmas Martapura Barat pada tahun 2013 berjumlah 188 kasus, 2014 berjumlah 274 kasus, serta pada tahun 2015 dengan jumlah 236 kasus. Dari uraian tersebut, peneliti ingin melakukan penelitian mengenai "Hubungan Perilaku Hidup Bersih dan Sehat dengan Kejadian Diare pada balita di Wilayah Kerja Puskesmas Martapura Barat tahun 2016.

\section{METODE PENELITIAN}

Penelitian ini dilaksanakan di wilayah puskesmas martapura barat yang merupakan penelitian survey analitik dengan rancangan cross sectional yaitu suatu penelitian yang mempelajari hubungan antara faktor-faktor risiko (independen) dengan faktor efek (dependen) dengan pendekatan observasi atau pengukuran pada waktu yang sama (Riyanto. A, 2011). Sebagai instrument penelitian digunakan kuesioner. Populasi dalam penelitian ini adalah jumlah ibu yang memiliki balita tahun 2015 sebanyak 311 orang, dengan jumlah sampel sebanyak 76 responden. Data yang diperoleh melalui observasi dan wawancara diolah secara manual kemudian diproses menggunakan komputer, disajikan bentuk tabel, dan dianalisa dengan uji Chi Square.

\section{HASIL}

Umur balita dalam penelitian ini terbanyak adalah balita umur 25-48 bulan $(46,1 \%)$ (Lihat lampiran, tabel 1). Umur ibu yang memiliki balita terbanyak adalah ibu umur 20 -29 tahun (60,5\%) (Lihat lampiran, tabel 2). Responden yang memiliki pendidikan yang baik, yaitu Sarjana $(1,3 \%)$ dan SLTA $(1,3 \%)$. Sedangkan responden yang berpendidikan rendah, (dibawah SLTA), yaitu SLTP $(18,4 \%)$ dan SD $(78,9 \%)$ (Lihat lampiran, tabel 3). Responden yang anak balitanya pernah mengalami diare dalam 3 bulan terakhir sebanyak 48 orang $(63,2 \%)$, sedangkan responden yang anak balitanya tidak mengalami diare sebanyak 28 orang $(36,8 \%)$ (Lihat lampiran, tabel 9). Dalam pemberian asi eksklusif, responden yang memberikan ASI Eksklusif pada balita sebanyak 50 responden $(65.8 \%$, sedangkan untuk ibu yang tidak memberikan ASI Eksklusif sebanyak 26 responden (34.2\%) (Lihat lampiran, tabel 4). Angka kejadian diare pada balita yang tidak diberikan Asi ek- 
sklusif sebanyak $24(92,3 \%)$, dan yang tidak mengalami diare sebanyak 2 (7,7\%), sedangkan angka kejadian diare untuk balita yang diberikan Asi eksklusif sebanyak 24 (48\%), dan yang tidak mengalami diare sebanyak 26 (52\%). Hasil analisa dengan menggunakan uji Chi Square didapatkan bahwa ada hubungan antara pemberian ASI eksklusif dengan kejadian diare pada balita di wilayah kerja Puskesmas Martapura Barat. (Lihat lampiran, tabel 10)

Penimbangan Balita dengan Kejadian Diare responden yang rutin menimbang balita sebanyak 73 responden $(96,1 \%)$, sedangkan responden yang tidak rutin menimbang balita sebanyak 3 responden $(3,9 \%)$ (Lihat lampiran, tabel 5). Angka kejadian diare pada balita yang tidak rutin ditimbang sebanyak 3 (100\%), sedangkan angka kejadian diare pada balita yang rutin ditimbang sebanyak $45(61,6 \%)$ dan tidak mengalami diare sebanyak 28 (38,4\%). Hasil analisa dengan uji Chi Square didapatkan tidak ada hubungan antara penimbangan balita dengan kejadia diare di wilayah kerja Puskesmas Martapura Barat. (Lihat lampiran, tabel 11)

Penggunaan Air Bersih dengan Kejadian Diare responden yang menggunakan air bersih sebanyak 12 responden (15,8\%), dan responden yang tidak menggunakan air bersih sebanyak 64 responden $(84,2 \%)$ (Lihat lampiran, tabel 6). Angka kejadian diare pada balita dengan responden tidak menggunakan air bersih sebanyak 44 (68,8\%), dan tidak mengalami diare sebanyak 20 (31,2\%), sedangkan angka kejadian diare dengan responden yang menggunakan air bersih sebanyak 4 (33,3\%), dan tidak mengalami diare sebanyak 8 (66,7\%). Hasil analisa uji Chi Square didapatkan ada hubungan antara penggunaan air bersih dengan kejadian diare pada balita di wilayah kerja Puskesmas Martapura Barat. (Lihat lampiran, tabel 12)

Penggunaan Jamban Sehat dengan Kejadian Diare responden yang menggunakan jamban sehat di wilayah kerja Puskesmas Martapura Barat sebanyak 26 responden $(34,2 \%)$, sedangkan responden yang tidak menggunakan jamban sehat sebanyak 50 responden $(65,8 \%)$ (Lihat lampiran, tabel 7). Angka kejadian diare pada balita dengan responden tidak menggunakan jamban sehat sehat sebanyak 36 (72\%), dan tidak mengala- mi diare sebanyak 14 (28\%). Sedangkan angka kejadian diare pada balita dengan responden menggunakan jamban sehat sebanyak 12 (46,2\%) dan tidak mengalami diare sebanyak 14 (53,8\%). Hasil analisis dengan uji Chi Squaredidapatkan bahwa ada hubungan antara penggunaan jamban sehat dengan kejadian diare pada balita. (Lihat lampiran, tabel 13)

Perilaku Cuci Tangan Pakai Sabun (CTPS) dengan Kejadian Diare responden dengan perilaku cuci tangan pakai sabun dikategorikan dalam 3 kategori, yaitu CTPS yang baik, CTPS cukup baik, dan CTPS kurang baik. Pada responden dengan kategori CTPS baik sebanyak $28(36,8 \%)$, CTPS cukup baik sebanyak 11 responden $(14,5 \%)$, dan CTPS kurang baik sebanyak 37 responden $(48,7 \%)$ (Lihat lampiran, tabel 8). Angka kejadian diare pada balita dengan responden CTPS baik sebanyak 10 $(35,7 \%)$, dan tidak mengalami diare sebanyak 18 (64,3\%). Balita mengalami diare pada responden CTPS cukup baik sebanyak $10(90,9 \%)$ dan tidak mengalami diare sebanyak 1 (9,1\%). Responden dengan perilaku CTPS kurang balita mengalami diare sebanyak $28(75,7 \%)$, dan tidak mengalami diare sebanyak 9 (24,3\%). Hasil uji statistik dengan uji Chi Square didapatkan ada hubungan antara perilaku CTPS dengan kejadian diare pada balita. Ibu yang menerapkan CTPS dengan baik dapat menghindarkan dari penularan bakteri. (Lihat lampiran, tabel 14)

\section{PEMBAHASAN}

Mayoritas ibu sudah memberikan bayinya Air susu ibu secara penuh selama 6 bulan. Hal ini dikarenakan sudah banyaknya informasi dari Puskesmas tentang pentingnya Asi untuk bayi, serta pada pendidikan ibu di wilayah Puskesmas Martapura Barat lebih banyak tamat SD, sehingga mayoritas ibu hanya bekerja menjadi ibu rumah tangga.

Pemberian ASI secara eksklusif berpengaruh pada sistem kekebalan bayi atau balita agar tidak mudah terserang penyakit terutama diare, banyak bukti ilmiah yang memperlihatkan bahwa ASI yang diberikan secara eksklusif selama 6 bulan pertama kehidupan bayi dapat mencukupi kebutuhan nutrisi bagi bayi untuk tumbuh dan 
berkembang. Balita yang diberikan ASI secara eksklusif yaitu tanpa makanan atau minuman tambahan lainnya selama 0-6 bulan kecuali obat/suplemen vitamin yang dianjurkan oleh dokter, dapat menghindari balita dari bahaya bakteri dan organisme lain yang menyebabkan diare. Bayi yang diberikan ASI Eksklusif lebih jarang menderita diare dibandingkan yang tidak di berikan ASI secara eksklusif. Hal ini disebabkan ASI mengandung komponen yang penting bagi pencegahan dan terapi diare akut (Soetjiningsih, 1997; Istyaningrum, 2010).

Saluran pencernaan bayi mudah mencerna ASI yang masuk ke dalam pencernaan, karena ASI mengandung enzim pencernaan sehingga dapat diserap sempurna oleh usus bayi dan tidak menimbulkan diare (Susanti,2004). Menurut Masri (2004), diare merupakan mekanisme pertahanan tubuh untuk mengeluarkan sesuatu yang merugikan atau racun dari dalam tubuh yang dikeluarkan bersama tinja akan mengakibatkan dehidrasi yang dapat berakibat kematian. Purwanti (2004) menambahkan, pembentukan kekebalan tubuh pada bayi umur 0-6 bulan belum sempurna.

Sejalan dengan penelitian Tumbelaka (2008) yang menyebutkan bahwa angka kejadian infeksi pada balita lebih sedikit bila dibandingkan dengan yang tidak mendapatkan ASI. selain itu, pada penelitian yang dilakukan Istyaningrum (2010) menyebutkan bahwa pemberian ASI eksklusif mempunyai hubungan bermakna dengan kejadian diare, hasilnya menunjukkan bayi yang diberikan ASI eksklusif yang terkena diare sebanyak 7 bayi (12.5\%), sedangkan bayi dengan tidak diberikan ASI eksklusif yang terkena diare sebanyak 33 bayi (66\%). Balita yang rutin ditimbang setiap bulan tidak mengalami diare karena pada penimbangan balita dapat mengetahui status gizi balita, jika balita mengalami penyakit maka akan cepat di diagnosa serta cepat pula penanganannya. Balita yang rutin ditimbang mengalami diare karena tidak ada beda secara khusus antara balita yang ditimbang dan tidak ditimbang, sama-sama dapat mengalami diare. Penimbangan balita erat kaitannya dengan keadaan status gizi balita, status gizi merupakan hal yang juga dapat menyebabkan resiko diare pada balita (Erdan,2005).

Responden dengan kategori menggunakan air bersih tidak diare karena pada sumber air yang bersih dan terlindungi, kuman penyakit atau bakteri penyebab diare tidak akan berkembang, sehingga balita tidak mudah terserang diare. Dan responden dengan kategori menggunakan air bersih tetapi tetap mengalami diare karena pada kalangan masyarakat masih kurang mengetahui cara pengolahan air yang baik. Serta pada penelitian di wilayah Puskesmas Martapura masih terdapat faktor lain yang menyebabkan diare. Sedangkan responden yang tidak menggunakan air bersih mengalami diare karena pada air yang tidak bersih kuman-kuman dan bakteri dapat berkembang. Sumber air yang tidak bersih jika digunakan dalam kebutuhan keluarga, dapat menularkan berbagai penyakit, khususnya diare. Dan responden yang tidak menggunakan air bersih tidak mengalami diare, karena responden mengetahui cara pengolahan air yang baik, dengan memasak air sebelum digunakan.

Pada penelitian yang telah dilakukan oleh Yulisa (2008) menunjukkan adanya hubungan yang signifikan antara sumber air bersih dengan kejadian diare. Penelitian Budiarso, 2003 (dalam Utari, 2011), menyatakan bahwa untuk menekan insiden diare dan sekaligus mencegah timbulnya penyakit fecal oral dapat dilakukan dengan memperbaiki keadaan hygiene sanitasi lingkungan. Upaya pemberantasan kejadian diare pada balita khususnya dan orang dewasa pada umumnya, tidak hanya terfokus pada faktor kesehatan lingkungannya. Kebiasaan dan perilaku hidup bersih dan sehat juga perlu mendapatkan perhatian. Kebiasaan dan perilaku yang baik dalam menyediakan air bersih, menggunakan air bersih, membuang sampah pada tempatnya, penggunaan jamban keluarga sebagai sarana pembuangan tinja, dapat mencegah terjadinya diare. Selain itu, komponen PHBS lainnya seperti : mencuci tangan pakai sabun, menjaga kebersihan dan kualitas air dari berbagai sumber polutan dapat mencegah diare (UNICEF, 2005 dalam Utari, 2011).

Ibu yang menggunakan jamban sehat terdapat diare karena didapatkan faktor lain yang dapat menyebabkan diare, seperti kebiasaan cuci tangan serta sarana air bersih. Pada ibu yang menggunakan jamban sehat terdapat 
balita yang tidak diare, karena penggunaan jamban sehat dapat menghindari pembuangan tinja yang sembarangan, tinja yang dibuang tidak pada semestinya, misalnya pada sumber air sungai, dapat membuat sungai terkontaminasi bakteri, sehingga jika masyarakat menggunakan air sungai tersebut dapat menjadi penyebab menularnya penyakit. Ibu yang menggunakan jamban sehat terdapat diare karena didapatkan faktor lain yang dapat menyebabkan diare, seperti kebiasaan cuci tangan serta sarana air bersih. Pada ibu yang menggunakan jamban sehat terdapat balita yang tidak diare, karena penggunaan jamban sehat dapat menghindari pembuangan tinja yang sembarangan, tinja yang dibuang tidak pada semestinya, misalnya pada sumber air sungai, dapat membuat sungai terkontaminasi bakteri, sehingga jika masyarakat menggunakan air sungai tersebut dapat menjadi penyebab menularnya penyakit. Penelitian ini sejalan pula dengan penelitian Chandra (2007) yang menyebutkan, pembuangan tinja secara tidak baik dan sembarangan mengakibatkan kontaminasi pada air, tanah, atau menjadi sumber infeksi dan akan mendatangkan bahaya bagi kesehatan. Penggunaan jamban akan bermanfaat untuk menjaga lingkungan bersih, sehat, dan tidak berbau. Jamban mencegah pencemaran sumber air yang ada di sekitarnya, jamban juga tidak mengundang datangnya lalat atau serangga yang dapat menjadi penular penyakit diare (Proverawati, 2012). Melalui tinja yang terinfeksi virus atau bakteri bias dihinggapi oleh binatang kemudian binatang tersebut hinggap ke makanan atau minuman, maka makanan atau minuman tersebut dapat menularkan diare ke orang yang memakannya (Widayono, 2008).

Perilaku CTPS yang baik pada ibu tetapi balita mengalami diare karena pada penelitian didapatkan lebih banyak anak usia yang diatas 1 tahun mengalami diare, hal ini dikarenakan pada anak usia tersebut sudah bisa bermain sendiri, serta memegang benda -benda yang ada disekitarnya, tanpa mengetahui kotor ataupun tidak. Sedangkan perilaku CTPS yang cukup tetapi balita mengalami diare, karena responden masih belum menerapkan CTPS secara benar, dari wawancara, mereka mengatakan lebih sering lupa untuk mencuci tangan pakai sabun sebelum atau sesudah beraktifitas. Perilaku CTPS yang kurang menyebabkan diare, karena pada tangan yang kotor dan tidak dicuci dengan sabun maka kuman penyakit akan menempel, sehingga saat kita makan ataupun minum kuman tersebut dapat masuk ke dalam tubuh manusia. Dalam penelitian Rosyidah (2014) menyatakan hal yang sama, bahwa terdapat hubungan antara perilaku CTPS dengan kejadian diare. Dimana perilaku yang baik maka kemungkinan terkena diare kecil, sedangkan perilaku yang kurang baik kemungkinan terkena diare lebih besar. Hal tersebut sesuai dengan kesimpulan Depkes RI (2009) bahwa sekitar 30 penelitian terkait diketahui cuci tangan dengan sabun dapat memangkas angka penderita diare hingga separuh. Penyakit diare seringkali diasosiasikan dengan keadaan air, namun secara akurat sebenarnya harus diperhatikan juga penanganan kotoran manusia seperti tinja dan air kencing, karena kumankuman penyakit penyebab diare berasal dari kotoran-kotoran ini. Kuman-kuman penyakit ini membuat manusia sakit ketika mereka masuk mulut melalui tangan yang telah terkontaminasi, air minum yang terkontaminasi, makanan mentah, dan peralatan makan yang tidak dicuci terlebih dahulu atau terkontaminasi akan tempat makannya yang kotor.

\section{KESIMPULAN DAN SARAN}

Penelitian ini menyimpulkan ada hubungan antara Perilaku Hidup Bersih dan Sehat (PHBS) meliputi pemberian asi eksklusif, penggunaan air bersih, penggunaan jamban sehat, dan perilaku CTPS dengan kejadian diare pada balita di wilayah kerja Puskesmas Martapura Barat, serta tidak ada hubungan antara PHBS penimbangan balita dengan kejadian diare pada balita di wilayah kerja Puskesmas Martapura Barat.

Dalam upaya pengendalian dan pencegahan penyakit diare di wilayah kerja Puskesmas Martapura Barat, perlu adanya peningkatan sarana air bersih dan kualitas jamban keluarga dari pemerintah agar dapat melengkapi sarana air bersih yang belum layak bagi masyarakat, serta pengadaan jamban sehat bagi masyarakat yang tidak memiliki jamban keluarga. Penambahan informasi serta peningkatan pemberian informasi dari 
unit pelayanan Puskesmas tentang Perilaku hidup bersih dan sehat yang baik dan benar.

\section{DAFTAR PUSTAKA}

Chandra B. 2007. Pengantar Kesehatan Lingkungan. Jakarta: ECG

Departemen Kesehatan Republik Indonesia. 2005. Pedoman Pemberantasan Penyakit Diare. Jakarta : Ditjen PPM dan PL. [online]. www.depkes.go.id

Depkes RI. 2007. Profil Kesehatan Indonesia. Jakarta.[online]. www.depkes.go.id

Dinas Kesehatan Kabupaten Banjar. 2015. Profil Kesehatan Kabupaten Banjar Tahun 2015.[online]. www.dinkes.banjarkab.go.id

Erdan. 2005. Faktor-faktor yang berhubungan dengan terjadinya diare akut. Skripsi, Universitas Gajah Mada. Yogyakarta.[online].

Fauziah. 2013. Hubungan Faktor Individu dan Karakteristik Sanitasi Air dengan Kejadian Diare pada Balita Umur 10-59 bulan di Kelurahan Sumur Batu Kecamatan Bantargebang Kota Bekasi Tahun 2013. Skripsi, UIN Syarif Hidayatullah. Jakarta.[online]. http:// repository.uinjkt.ac.id

Istyaningrum Y. 2010. Hubungan Antara Pemberian ASI Ekslusif dengan Kejadian Diare dan Faktor-Faktor Risiko pada Bayi Berusia 6-12 Bulan di Kelurahan Bendungan Kecamatan Cilegon pada Bulan Agustus 2010. Skripsi, UIN Syarif Hidayatullah. Jakarta. [online]. http:// repository.uinjkt.ac.id

Masri Siti Habsyah. 2004. Diare Penyebab Kematian 4 Juta Balita Per Tahun. http://www.waspada.co.id/serba -serbi/kesehatan/artikel.,php? artikelid=

Proverawati, Atikah. 2012. Perilaku Hidup Bersih dan Sehat (PHBS). Yogyakarta: Nuha Medika.

Riyanto. A. 2011. Aplikasi Metodologi Penelitian Kesehatan. Yogyakarta: Nuha Medika

Rosyidah. (2014). Hubungan perilaku cuci tangan terhadap kejadian diare. Artikel Ilmiah. Diakses pada 22 Juni 2016 dari repository.uinjkt.ac.id/dspace/.../ Alif\%20Nurul\%20Rosyidah\%20-\%20 fkik\%20.pdf.
Soepardi. J. 2011. Buletin Diare. Jakarta. [online]. www.depkes.go.id

Soetjiningsih. 1997. Seri Gizi Klinik ASI Petunjuk untuk Tenaga Kesehatan. Jakarta: Penerbit Buku Kedokteran EGC. 61175-35k (Akses 29 Maret 2011)

Susanti, Nuraini. 2004. Usia Tepat Mendapat Makanan Tambahan. http:// www.tabloit-nakita.com/artikel-ph3? edisi=0406rubrik (Akses 29 Maret 2011)

Utari T. 2011. Hubungan perilaku bersih hidup dan sehat dengan kejadian diare di wilayah kerja Puskesmas Delangu. Dalam http://Isjd.Pdii.Lipi.go.id/ admin/jurnal/11095361.pdf. diakses: 24 Februari 2016.

Widayono. 2008. Penyakit Tropis Epidemiologi, Penularan, Pencegahan dan Pemberantasannya. Jakarta: Erlangga.

Yulisa. 2008. faktor-faktor yang mempengaruhi kejadian diare pada anak balita (studi pada masyarakat etnis dayak kelurahan kasongan baru kecamatan kentingan hilir kabupaten kentingan kalimantan tengah). Skripsi fakultas kesehatan masyarakat. universitas diponegoro. 
LAMPIRAN

Tabel 1. Distribusi Frekuensi Responden Berdasarkan Umur Balita

\begin{tabular}{lll}
\hline Umur Balita (Bulan) & $\mathrm{f}$ & $\%$ \\
\hline $0-12$ & 22 & 28.9 \\
$13-24$ & 19 & 25 \\
$25-48$ & 35 & 46.1 \\
Jumlah & 76 & 100 \\
\hline \multicolumn{2}{l}{ Sumber : } & Data Primer, 2016
\end{tabular}

Tabel 2. Distribusi Frekuensi Responden Berdasarkan Umur Ibu

\begin{tabular}{lcc}
\hline Umur Ibu (tahun) & f & $\%$ \\
\hline $20-29$ & 46 & 60.5 \\
$30-39$ & 29 & 38.2 \\
40 & 1 & 1.3 \\
Jumlah & 76 & 100 \\
\hline
\end{tabular}

Sumber: $\quad$ Data Primer, 2016

Tabel 3. Distribusi Frekuensi Responden Berdasarkan Pendidikan Ibu

\begin{tabular}{lrr}
\hline Pendidikan Ibu & $\mathrm{f}$ & $\%$ \\
\hline Sarjana & 1 & 1.3 \\
SLTA & 1 & 1.3 \\
SLTP & 14 & 18.4 \\
SD & 60 & 78.9 \\
Jumlah & 76 & 100 \\
\hline Sumber: & Data Primer, 2016
\end{tabular}

Tabel 4. Distribusi Frekuensi Pemberian Asi Eksklusif

\begin{tabular}{lll}
\hline Pemberian ASI Eksklusif & f & $\%$ \\
\hline ASI Eksklusif & 50 & 65.8 \\
Tidak ASI Eksklusif & 26 & 34.2 \\
Jumlah & 76 & 100 \\
\hline Sumber: Data Primer, 2016
\end{tabular}


Tabel 5. Distribusi Frekuensi Penimbangan Balita

\begin{tabular}{lrc}
\hline Penimbangan Balita & \multicolumn{1}{c}{$\mathrm{f}$} & $\%$ \\
\hline Rutin ditimbang & 73 & 96.1 \\
Tidak rutin ditimbang & 3 & 3.9 \\
Jumlah & 76 & 100 \\
\hline
\end{tabular}

Sumber : $\quad$ Data Primer, 2016

Tabel 6. Distribusi Frekuensi Penggunaan Air Bersih

\begin{tabular}{lll}
\hline Penggunaan Air Bersih & $\mathrm{f}$ & $\%$ \\
\hline Menggunakan & 12 & 15.8 \\
Tidak Menggunakan & 64 & 84.2 \\
Jumlah & 76 & 100 \\
\hline
\end{tabular}

Sumber : $\quad$ Data Primer, 2016

Tabel 7. Distribusi Frekuensi Penggunaan Jamban Sehat

\begin{tabular}{lll}
\hline Penggunaan Jamban Sehat & f & $\%$ \\
\hline Menggunakan & 26 & 34.2 \\
Tidak Menggunakan & 50 & 65.8 \\
Jumlah & 76 & 100 \\
\hline
\end{tabular}

Sumber : $\quad$ Data Primer, 2016

Tabel 8. Distribusi Frekuensi Perilaku Cuci Tangan Pakai Sabun

\begin{tabular}{lll}
\hline Perilaku Cuci tangan pakai sabun & f & $\%$ \\
\hline Baik & 28 & 36.8 \\
Cukup & 11 & 14.5 \\
Kurang & 37 & 48.7 \\
Jumlah & 76 & 100 \\
\hline
\end{tabular}

Sumber : $\quad$ Data Primer, 2016

Tabel 9. Distribusi Kejadian Diare Pada Balita

\begin{tabular}{lll}
\hline Kejadian Diare pada Balita & $\mathrm{f}$ & $\%$ \\
\hline Tidak Diare & 28 & 36.8 \\
Diare & 48 & 63.2 \\
Jumlah & 76 & 100 \\
\hline
\end{tabular}

Sumber : $\quad$ Data Primer, 2016 
Tabel 10. Analisis Hubungan Pemberian ASI Eksklusif Dengan Kejadian Diare Pada Balita

Pemberian ASI Eksklusif

Kejadian Diare pada Balita

\begin{tabular}{|c|c|c|c|c|c|c|c|}
\hline \multicolumn{3}{|c|}{ Tidak Diare } & \multicolumn{2}{|c|}{ Diare } & \multirow{2}{*}{$\begin{array}{r}\text { Total } \\
\text { Jumlah }\end{array}$} & \multicolumn{2}{|c|}{ P value } \\
\hline & imlah & $\%$ & Jumlah & $\%$ & & $\%$ & 0,000 \\
\hline ASI Eksklusif & 26 & 52 & 24 & 48 & 50 & 100 & \\
\hline $\begin{array}{l}\text { Tidak ASI Ek- } \\
\text { sklusif }\end{array}$ & 2 & 7.7 & 24 & 92.3 & 26 & 100 & \\
\hline Jumlah & 28 & 36.8 & 48 & 63.2 & 76 & 100 & \\
\hline
\end{tabular}

Tabel 11. Analisis Hubungan Penimbangan Balita Dengan Kejadian Diare Pada Balita

Penimbangan Balita Kejadian Diare pada Balita

\begin{tabular}{|c|c|c|c|c|c|c|c|}
\hline & \multicolumn{2}{|c|}{ Tidak Diare } & \multicolumn{2}{|l|}{ Diare } & \multicolumn{2}{|c|}{ Total } & $P$ value \\
\hline & Jumlah & $\%$ & Jumlah & $\%$ & Jumlah & $\%$ & 0,293 \\
\hline $\begin{array}{l}\text { Rutin } \\
\text { ditimbang }\end{array}$ & 28 & 38.4 & 45 & 61.6 & 73 & 100 & \\
\hline $\begin{array}{l}\text { Tidak rutin } \\
\text { ditimbang }\end{array}$ & 0 & 7.7 & 3 & 92.3 & 3 & 100 & \\
\hline Jumlah & 28 & 36.8 & 48 & 63.2 & 76 & 100 & \\
\hline
\end{tabular}

Sumber : $\quad$ Data Primer, 2016

Tabel 12. Analisis Hubungan Penggunaan Air Bersih Dengan Kejadian Diare Pada Balita

Penggunaan Air Bersih Kejadian Diare pada Balita

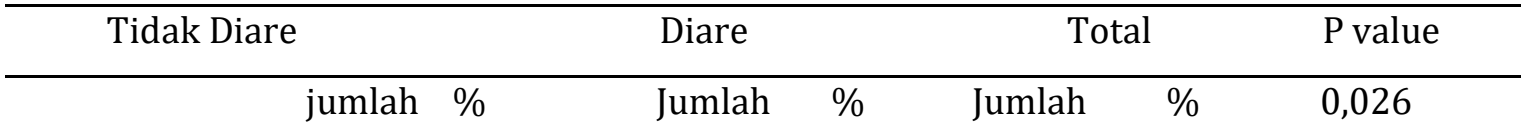

\begin{tabular}{|c|c|c|c|c|c|c|}
\hline Menggunakan & 8 & 66.7 & 4 & 33.3 & 12 & 100 \\
\hline $\begin{array}{l}\text { Tidak } \\
\text { Menggunakan }\end{array}$ & 20 & 31.2 & 44 & 68.8 & 64 & 100 \\
\hline Jumlah & 28 & 36.8 & 48 & 63.3 & 76 & 100 \\
\hline
\end{tabular}

Sumber : $\quad$ Data Primer, 2016 
Tabel 13. Analisis Hubungan Penggunaan Jamban Sehat Dengan Kejadian Diare

Pada Balita

\begin{tabular}{|c|c|c|c|c|c|c|c|}
\hline \multicolumn{4}{|c|}{ Penggunaan Jamban Sehat } & \multicolumn{4}{|c|}{ Kejadian Diare pada Balita } \\
\hline \multirow[t]{2}{*}{ Tidak Diare } & & & Diar & & & & $P$ value \\
\hline & Jumlah & $\%$ & Jumlah & $\%$ & Jumlah & $\%$ & 0,049 \\
\hline Menggunakan & 14 & 53.8 & 12 & 46.2 & 26 & 100 & \\
\hline Tidak Menggunakan & 14 & 28 & 36 & 72 & 50 & 100 & \\
\hline Jumlah & 28 & 36.8 & 48 & 63.2 & 76 & 100 & \\
\hline
\end{tabular}

Sumber : Data Primer 2016

Tabel 14.

Analisis Hubungan Perilaku Cuci Tangan Pakai Sabun Dengan Kejadian Diare Pada Balita

\begin{tabular}{|c|c|c|c|c|c|c|c|}
\hline \multicolumn{3}{|c|}{ Cuci Tangan Pakai Sabun } & & \multicolumn{4}{|c|}{ Kejadian Diare pada Balita } \\
\hline \multicolumn{3}{|c|}{ Jumlah Tidak Diare } & \multicolumn{2}{|c|}{ Diare } & \multicolumn{2}{|c|}{ Total } & \multirow{2}{*}{$\frac{P \text { value }}{0,001}$} \\
\hline & Jumlah & $\%$ & Jumlah & $\%$ & Jumlah & $\%$ & \\
\hline Baik & 18 & 64.3 & 10 & 35.7 & 28 & 100 & \\
\hline Cukup & 1 & 9.1 & 10 & 90.9 & 11 & 100 & \\
\hline Kurang & 9 & 24.3 & 28 & 75.7 & 37 & 100 & \\
\hline Jumlah & 28 & 36.8 & 48 & 63.2 & 76 & 100 & \\
\hline
\end{tabular}

Sumber : Data Primer 2016 